\title{
IMPLEMENTASI PERATURAN PRESIDEN NOMOR 54 TAHUN 2010 TENTANG PENGADAAN BARANG DAN JASA PEMERINTAH DI KABUPATEN SUKOHARJO
}

\author{
Yuli Isnandar \\ Email: yuliisnandar@gmail.com \\ Pegawai Bank Rakyat Indonesia Surakarta \\ Universitas Sebelas Maret Surakarta \\ HariPurwadi \\ Email: h_purwadie@yahoo.com \\ I Gusti Ayu Ketut RH \\ Email: i.gustiayuketut@gmail.com \\ Dosen Fakultas Hukum Universitas Sebelas Maret Surakarta
}

\begin{abstract}
This article aims to describe the implementation of procurement auction policy of goods and services in Sukoharjo before and after the Presidential Regulation No. 54 of 2010 on Procurement of Government Goods and Services (e-procurement), to explain constraints in the implementation of procurement auction policy of goods and services in Kabupaten Sukoharjo after the issuance of Presidential Regulation No. 54 of 2010 on Procurement of Government Goods and Services (e-procurement) and its solution. This type of legal research is sociological or non-doctrinal with qualitative research methods that aim to know the Implementation of Presidential Regulation No. 54 of 2010 on Procurement of Government Goods and Services (Case Study of Implementation of E-Procurement in Sukoharjo District). Data collection techniques used interview techniques, literature study and documentation. The result of this research is in the implementation of the policy of auction of procurement of goods and services in Sukoharjo District before the Presidential Regulation Number 54 Year 2010 concerning Procurement of Government Goods and Services (e-procurement), there is Presidential Regulation Number 54 Year 2010 concerning Procurement of Government Goods and Services -procurement) in Sukoharjo Regency in accordance with Presidential Decree No. 80 of 2003 on Guidelines for Procurement of Government Goods and Services. Implementation of procurement auction policy of goods and services in Sukoharjo District after the Presidential Regulation Number 54 Year 2010 concerning Procurement of Government Goods and Services (e-procurement) that is, the length of time required in the procurement of goods/services in LPSE Sukoharjo District is 1) fiscal year. The time required to disseminate Presidential Regulation No. 54/2010 on Procurement of Goods/Services of the Government of Sukoharjo Regency is not maximal, since the socialization provided by the Sukoharjo District Government is very limited, since this socialization is only given the opportunity to the Official Commitment Officer/Procurement Committee and Civil Servants who are prepared as technical personnel managing goods/services Government that has a certificate Procurement of goods/services.
\end{abstract}

Keywords: Procurement of goods and services; E-Procurement; LPSE 


\begin{abstract}
Abstrak
Artikel ini bertujuan untuk mendeskripsikan pelaksanaan kebijakan lelang pengadaan barang dan jasa di Kabupaten Sukoharjo sebelum dan sesudah adanya Peraturan Presiden Nomor 54 Tahun 2010 tentang Pengadaan Barang dan Jasa Pemerintah (e-procurement), untuk menjelaskan kendala dalam pelaksanaan kebijakan lelang pengadaan barang dan jasa di Kabupaten Sukoharjo setelah adanya Peraturan Presiden Nomor 54 Tahun 2010 tentang Pengadaan Barang dan Jasa Pemerintah (e-procurement) dan solusinya. Jenis penelitian hukum ini adalah sosiologis atau non doktrinal dengan metode penelitian kualitatif yang bertujuan untuk mengetahui Implementasi Peraturan Presiden Nomor 54 Tahun 2010 tentang Pengadaan Barang dan Jasa Pemerintah (Studi Kasus Pelaksanaan E-Procurement di Kabupaten Sukoharjo). Teknik pengumpulan data menggunakan teknik wawancara, studi kepustakaan dan dokumentasi. Hasil penelitian ini adalah dalam pelaksanaan kebijakan lelang pengadaan barang dan jasa di Kabupaten Sukoharjo sebelum adanya Peraturan Presiden Nomor 54 Tahun 2010 tentang Pengadaan Barang dan Jasa Pemerintah (e-procurement), terdapat Peraturan Presiden Nomor 54 Tahun 2010 tentang Pengadaan Barang dan Jasa Pemerintah (e-procurement) di Kabupaten Sukoharjo sesuai dengan Keputusan Presiden Nomor 80 Tahun 2003 TentangPedoman Pelaksanaan Pengadaan Barang dan Jasa Pemerintah. Pelaksanaan kebijakan lelang pengadaan barang dan jasa di Kabupaten Sukoharjo setelah adanya Peraturan Presiden Nomor 54 Tahun 2010 tentang Pengadaan Barang dan Jasa Pemerintah (e-procurement) yaitu, lamanya waktu yang dibutuhkan dalam pelaksanaan pengadaan barang/jasa di di LPSE Kabupaten Sukoharjo adalah 1 (satu) tahun anggaran. Waktu yang dibutuhkan dalam melakukan sosialisasi Peraturan Presiden Nomor 54 Tahun 2010 tentang Pengadaan barang/jasa Pemerintah untuk Kabupaten Sukoharjo tidaklah maksimal, karena sosialisasi yang diberikan oleh Pemerintah Kabupaten Sukoharjo sangatlah dibatasi, karena sosialisasi ini hanya diberikan kesempatan kepada Pejabat Pembuat Komitmen Pejabat/Panitia Pengadaan dan Pegawai Negeri Sipil yang dipersiapkan sebagai tenaga teknis pengelola barang/ jasa Pemerintah yang telah memiliki sertifikat Pengadaan barang/jasa.
\end{abstract}

Kata Kunci: Pengadaan barang dan jasa; E-Procurement; LPSE

\section{A. Pendahuluan}

Upaya Pemerintah Indonesia dalam mewujudkan good governance adalah dengan cara melakukan reformasi dalam segala kegiatan pemerintahan ataupun pelayanan publik melalui pemanfaatan teknologi informasi atau biasa disebut dengan e-government. Pencanangan e-government di Indonesia, baru dimulai dan diperkenalkan pada tanggal 24 April Tahun 2001 melalui Intruksi Presiden Nomor 6 Tahun 2001 tentang Telematika (Telekomunikasi, Media dan Informatika), yang menjelaskan bahwa aparat pemerintah harus menggunakan teknologi telematika dalam mewujudkan good governance dan mempercepat proses demokrasi (Nico Ardianto, 2007).

Penerapan e-Government merupakan suatu mekanisme yang dapat diterapkan oleh pemerintah untuk menjawab segala permasalahan berkenaan dengan pelayanan publik bagi masyarakat. Teknologi informasi dan komunikasi merupakan salah satu teknologi yang berkembang dengan pesat dan dapat dimanfaatkan untuk mencegah tindak pidana korupsi. Melalui penerapan electronic government (e-governmant) dapat di cegah terjadinya mal administrasi dalam pelayanan publik. Pengadaan barang dan jasa di lingkungan instansi pemerintah yang sarat 
dengan korupsi, kolusi dan nepotisme (F.H Edy Nugroho, 2014).

Penerapan e-government yang telah dilakukan pemerintah Indonesia beberapa tahun belakangan ini adalah melalui electronic procurement (e-procurement). E-procurement merupakan salah satu layanan e-government yang merupakan proses pengadaan barang/jasa pemerintah yang pelaksanaannya dilakukan secara elektronik, berbasis web/internet dengan memanfaatkan fasilitas teknologi informasi dan komunikasi yang meliputi pelelangan umum secara elektronik yang diselenggarakan oleh Layanan Pengadaan Secara Elektronik (LPSE). Berdasarkan Perpres Nomor 54 Tahun 2010 tentang pengadaan barang dan jasa, semua instansi-instansi pemerintah memiliki kewajiban melaksanakan e-procurement pada tahun 2012. Melalui e-procurement telah terjadi efisiensi penggunaan anggaran instansi pemerintah sebesar $11 \%$ pada tahun 2010 , dan berhasil menghemat $14 \%$.

Perkembangan teknologi saat ini sudah seharusnya dijadikan suatu momen bagi Pemerintah Kabupaten Sukoharjo dalam meningkatkan transparansi dan memberikan kemudahan bagi masyarakat untuk memperoleh layanan informasi mengenai segala kegiatan Pemerintahan di Kabupaten Sukoharjo seperti halnya penerapan sistem informasi yang di sebut e-lelang. Pelaksanaan e-lelang di Pemerintah Kabupaten Sukoharjo sendiri dijalankan oleh Layanan Pengadaan Barang/Jasa Secara Elektronik (LPSE) sebagai unit kerja Badan Perencanaan Pembangunan Daerah (Bappeda) Kabupaten Sukoharjo. LPSE adalah unit kerja yang dibentuk diberbagai instansi dan pemerintah daerah untuk melayani Unit Layanan Pengadaan (ULP) atau Panitia/Pokja ULP Pengadaan yang akan melaksanakan pengadaan secara elektronik. Seluruh ULP dan Panitia/Pokja ULP Pengadaan dapat menggunakan fasilitas LPSE yang terdekat dengan tempat kedudukannya. LPSE melayani registrasi penyedia barang dan jasa yang berdomisili di wilayah kerja LPSE yang bersangkutan (lpse.sukoharjokab.go.id).

Sesuai dengan pengoperasian Sistem Pengadaan Secara Elektronik (SPSE), Proses pendaftaran e-lelang di Kabupaten Sukoharjo ini memiliki dua tahap pendaftaran bagi peserta yang akan mengikuti pelaksanaan e-lelang. Masalah yang terjadi pada penyelenggaran e-lelang di Kabupaten Sukoharjo, bahwa hambatan untuk para calon peserta lelang dalam mengikuti pelaksanaan lelang yaitu mengenai jaringan internet yang kurang memadai yang mengakibatkan sulitnya untuk meng-upload dokumen yang akan dikirimkan ke LPSE Kabupaten Sukoharjo melalui website LPSE Kabupaten Sukoharjo atau pengiriman dokumen melalui e-mail masih sering terjadi kegagalan pengiriman yang disebabkan lemahnya jaringan internet yang digunakan peserta lelang dalam mengikuti e-lelang.

Informasi pelayanan dapat dilihat langsung di website LPSE Kabupaten Sukoharjo, pada kenyataanya, dalam melakukan pendaftaran, para calon penyedia barang/jasa masih merasa kesulitan. Proses pendaftaran yang masih berbelit-belit, dimana calon penyedia barang/ jasa Pemerintah diharuskan mendownload informasi mengenai prosedur pendaftaran. Kemudahan bagi masyarakat yang terbiasa dengan media elektronik dan internet, namun hambatan bagi masyarakat yang tidak tebiasa dengan media elektronik dan internet. Tidak mudah dalam menerapkan sebuah teknologi baru. Penulis tertarik untuk melakukan penelitian mengenai Pengadaan barang/jasa yang diadakan oleh pemerintah di Kabupaten Sukoharjo dikarenakan tidak mudah untuk melaksanakan sebuah kebijakan baru terlebih dalam hal penggunaan teknologi informasi seperti halnya e-procurement. 
Berdasarkanuraiandiatasdalam artikel ini dibahas bagaimana Implementasi Peraturan Presiden Nomor 54 Tahun 2010 Tentang Pengadaan Barang dan Jasa Pemerintah kabupaten sukoharjo.

\section{B. MetodePenelitian}

Jenis penelitian hukum ini adalah sosiologis atau non doktrinal dengan metode penelitian kualitatif yang bertujuan untuk mengetahui Implementasi Peraturan Presiden Nomor 54 Tahun 2010 tentang Pengadaan Barang dan Jasa Pemerintah (Studi Kasus Pelaksanaan E-Procurement di Kabupaten Sukoharjo).Penelitian dilakukan di lelang pengadaan barang dan jasa Kabupaten Sukoharjo.Pendekatan dalam penelitian ini dipergunakan pendekatan kasus (case approach) yang mempelajari ratio decidendi, yaitu alasan hukum yang digunakan oleh hakim untuk mengambil keputusan.

Teknik pengumpulan data dalam pnelitian ini melalui wawancara, studi kepustakaan dan dokumentasi. Data primer dalam penelitian inidiperoleh secara langsung dari wawancara, yaitu orang yang dijadikan key informant. Adapun sumber data primer adalah hasil wawancara dengan penyedia layanan yaitu personil pada LPSE Kabupaten Sukoharjo dan pelaku e procurement, sedangkan data sekunder diperoleh dari putusan pengadilan, dokumen-dokumen, tulisan-tulisan, buku ilmiah dan literatur-literatur yang mendukung.

Teknik analisis data yang digunakan dalam penelitian ini adalah analisis data kualitatif. Dalam hal ini terdapat tiga komponen analisis yaitu reduksi data, sajian data dan penarikan kesimpulan atau verifikasinya. Sedangkan aktifitas dilakukan dalam bentuk interaktif dengan proses pengumpulan data sebagai proses siklus.

\section{Hasil Penelitian dan Pembahasan}

1. Pelaksanaan kebijakan lelang pengadaan barang dan jasa di Kabupaten Sukoharjo sebelum dan sesudah adanya Peraturan Presiden Nomor 54 Tahun 2010 tentang Pengadaan Barang dan JasaPemerintah (e-procurement)

Pelaksaan pengadaan barang dan jasa di Kabupaten Sukoharjo sebelum adanya Peraturan Presiden Nomor 54 Tahun 2010 tentang Pengadaan barang dan jasa pemerintah di jalankan berdasarkan Keppres Nomor 80 Tahun 2003 tentang Pedoman Pelaksanaan Pengadaan Barang dan Jasa.

Pasal 1 Ayat (1), dijelaskan mengenai maksud Pengadaan Barang dan Jasa yang merupakan pengadaan barang dan jasa yang dibiayai dengan APBN/APBD, baik yang dilaksanakan secara swakelola maupun oleh penyedia barang/jasa.Dalam pengadaan barang dan jasa pemerintah memuat kebijakan umum pemerintah seperti termuat dalam Keppres Nomor 80 Tahun 2003 Pasal 4, antara lain:

a. Meningkatkan penggunaan produksi dalam negeri, rancang bangun dan perekayasaan nasional yang sasarannya adalah memperluas lapangan kerja dan mengembangkan industri dalam negeri dalam rangka meningkatkan daya saing barang dan jasa produksi dalam negeri pada perdagangan internasional.

b. Meningkatkan peran serta usaha kecil termasuk koperasi kecil dan kelompok masyarakat dalam pengadaan barang dan jasa.

c. Menyederhanakan ketentuan dan tata cara untuk mempercepat proses pengambilan keputusan dalam pengadaan barang dan jasa. 
d. Meningkatkan profesionalisme, kemandirian, dan tanggung jawab pengguna barang dan jasa, panitia/ pejabat pengadaan, dan penyedia barang dan jasa.

e. Meningkatkan penerimaan negara melalui sektor pajak.

f. Menumbuhkembangkan peran serta usaha nasional.

g. Mengharuskan pelaksanaan pemilihan penyesia barang dan jasa dilakukan di dalam wilayah Negara Kesatuan Republik Indonesia

h. Mengharuskan pengumuman secara terbuka rencana pengadaan barang dan jasa kecuali pengadaan barang dan jasa yang bersifat rahasia pada setiap awal pelaksanaan anggaran kapada masyarakat luas.

i. Mengumumkan kegiatan pengadaan barang dan jasa pemerintah secara terbuka melalui surat kabar nasional dan/atau surat kabar provinsi.

Dalam pelaksaaan pengadaan barang dan jasa pemerintah, baik oleh pengguna barang dan jasa, penyedia barang dan jasa, maupun para pihak yang terkait dalam pelaksanaan pengadaan barang dan jasa harus mematuhi dan mentaati etika sebagaimana telah diatur dalam Keppres Nomor 80 Tahun 2003 Pasal 5, antara lain:

1. Melaksanakan tugas secara tertib, disertai rasa tanggung jawab untuk mencapai sasaran kelancaran dan ketepatan tercapainya tujuan pengadaan barang dan jasa.

2. Bekerja secara profesional dan mandiri atas dasar kejujuran, serta menjaga kerahasiaan dokumen pengadaan barang dan jasa yang seharusnya dirahasiakan untuk mencegah terjadinya penyimpangan dalam pengadaan barang dan jasa.
3. Tidak saling mempengaruhi baik langsung maupun tidak langsung untuk mencegah dan menghindari terjadinya persaingan tidak sehat.

4. Menerima dan bertanggung jawab atas segala keputusan yang ditetapkan sesuai dengan kesepakatan para pihak.

5. Menghindari dan mencegah terjadinya pertentangan kepentingan para pihak yang terkait, langsung maupun tidak langsung dalm proses pengadaan barang dan jasa (conflict of interest).

6. Menghindari dan mencegah terjadinya pemborosan dan kebocoran keuangan negara dalam pengadaan barang dan jasa.

7. Menghindari dan mencegah penyalahgunaan wewenang dan/atau kolusi dengan tujuan keuntungan pribadi, golongan, atau pihak lain yang secara langsung atau tidak langsung merugikan negara.

8. Tidak menerima, tidak menawarkan atau tidak menjanjikan untuk memberi atau menerima hadiah, imbalan berupa apa saja kepada siapapun yang diketahui atau patut dapat diduga berkaitan dengan pengadaan barang dan jasa.

Dalam pelaksanaan pengadaan barang dan jasa pemerintah, menurut Keppres Nomor 80 Tahun 2003 Pasal 6 dapat dilakukan melalui 2 cara, antara lain :

1. Dengan menggunakan penyedia barang dan jasa

2. Dengan cara swakelola

Pengguna barang dan jasa berdasarkan Keppres Nomor 80 Tahun 2003 Pasal 9 Ayat (1), harus memenuhi persyaratapersyaratan sebagai berikut :

1. Memiliki integritas moral

2. Memiliki disiplin tinggi 
3. Memiliki tanggung jawab dan kualifikasi teknis serta manajerial untuk melaksanakan tugas yang dibebankan kepadanya

4. Memiliki sertifikatkeahlian pengadaan barang dan jasa pemerintah

5. Memiliki kemampuan untuk mengambil keputusan, bertindak tegas dan keteladanan dalam sikap dan perilaku serta tidak pernah terlibat $\mathrm{KKN}$

Tugas pokok dari pengguna barang /jasa dalam pengadaan barang dan jasa pemerintah, antara lain :

1. Menyusun perencanaan pengadaan barang dan jasa.

2. Mengangkat panitia/pejabat pengadaan barang dan jasa.

3. Menetapkan paket-paket disertai ketentuan mengenai peningkatan penggunaan produksi dalam negeri dan peningkatan pemberian kesempatan bagi usaha kecil termasuk koperasi kecil, serta kelompok masyarakat.

4. Menetapkan dan mengesahkan harga perkiraan sendiri (HPS), jadwal, tata cara pelaksanaan dan lokasi pengadaan yang disusun panitia pengadaan.

5. Menetapkan dan mengesahkan hasil pengadaan panitia/pejabat pengadaan sesuai kewenangannya.

6. Menetapkan besaran uang muka yang menjadi hak penyedia barang dan jasa sesuai ketentuan yang berlaku.

7. Menyiapkan dan melaksanakan perjanjian/kotrak dengan pihak penyedia barang dan jasa.

8. Melaporkan pelaksanaan/penyelesaian pengadaan barang dan jasa kepada pemimpin instansinya.

9. Mengendalikan pelaksanaan perjanjian/kontrak.

10. Menyerahkan aset hasil pengadaan barang dan jasa dan aset lainnya kepada Menteri/Panglima TNI/ Kapolri/Pemimpin

11. Lembaga/Gubernur/Bupati/Walikota/ Dewan Gubernur BI/Pemimpin BHMN/ Direksi BUMN/BUMD dengan berita acara penyerahan.

Metode Pemilihan Penyedia Barang dan jasa Pemborongan/Jasa Lainnya sebagaimana yang telah diatur dalam Pasal 17 Keppres Nomor 80 Tahun 2003 dan telah dirubah dengan Perpres Nomor 8 Tahun 2006, antara lain, dalam pemilihan penyedia barang dan jasa pemborongan/jasa lainnya, pada prinsipnya dilakukan melalui metode pelelangan umum. Pelelangan umum adalah metode pemilihan penyedia barang danjasa yang dilakukan secara terbuka dengan pengumuman secara luas sekurang-kurangnya di satu surat kabar nasional dan/atau satu surat kabar provinsi.

Metode Penyampaian Dokumen Penawaran Pada Pemilihan Penyedia Barang dan jasa Pemborongan/Jasa Lainnya Berdasarkan atas Pasal 18 Keppres Nomor 80 Tahun 2003 bahwa dalam pemilihan penyedia barang dan jasa pemborongan/jasa lainnya dapat dipilih salah 1 (satu) dari 3 (tiga) metode penyampaian dokumen penawaran berdasarkan jenis barang dan jasa yang akan diadakan dan metode penyampaian dokumen penawaran tersebut harus dicantumkan dalam dokmen lelang yang meliputi antara lain :

1. Metode satu sampul, adalah penyampaian dokumen penawaran yang terdiri dari persyaratan administrasi, teknis, dan penawaran harga yang dimasukkan ke dalam 1 (satu) sampul tertutup kepada panitia/pejabat pengadaan.

2. Metode dua sampul, adalah penyampaian dokumen penawaran yang 
persyaratan administrasi dan teknis dimasukkan dalam sampul tertutup I, sedangkan harga penawaran dimasukkan dalam sampul tertutup II, selanjutnya sampul I dan sampul II dimasukkan ke dalam 1 (satu) sampul (sampul penutup) dan disampaikan kepada panitia/pejabat pengadaan.

3. Metode dua tahap, adalah penyampaian dokumen penawaran yang persyaratan administrsi dan teknis dimasukkan dalam sampul tertutup I, sedangkan harga penawaran dimasukkan dalam sampul tertutup II, yang penyampaiannya dilakukan dalam 2 (dua) tahap secara terpisah dan dalam waktu yang berbeda.

4. Evaluasi Penawaran Pada Pemilihan Penyedia Barang dan jasa Pemborongan/Jasa Lainnya.

Dalam mengevaluasi dokumen penawaran, panitia/pejabat pemilihan penyedia barang.jasa tidak diperkenankan mengubah, menambah, dan mengurangi kriteria dan tata cara evaluasi tersebut denga alasan apapun dan atau melakukan tindakan lain yang bersifat post bidding.

Berdasarkan Pasal 27 Keppres Nomor 80 Tahun 2003, bahwa peserta pemilihan penyedia barang dan jasa yang merasa dirugikan, baik secara sendiri maupun bersama-sama dengan peserta lainnya, dapat mengajukan surat sanggahan kepada pengguna barang dan jasa apabila ditemukan :

a. Penyimpangan terhadap ketentuan dan prosedur yang telah ditetapkan dalam dokumen pemilihan penyedia barang dan jasa.

b. Rekayasa tertentu sehingga menghalangi terjadinya persaingan yang sehat.

c. Penyalahgunaan wewenang oleh panitia, pejabat pengadaan dan/atau pejabat yang berwenang lainnya.

d. Adanya unsur KKN di antara peserta pemilihan penyedia barang dan jasa.

e. Adanya unsur KKN di antara peserta dengan anggota panitia, pejabat pengadaan dan/atau pejabat yang berwenang lainnya.

Pengguna barang dan jasa wajib memberikan jawaban selambatlambatnya 5 (lima) hari kerja sejak surat sanggahan diterima. Apabila penyedia barang dan jasa tidak puas terhadap jawaban pengguna barang dan jasa tersebut maka dapat mengajukan surat sanggahan banding. Surat sanggahan banding disampaikan kepada Menteri/ Panglima TNI/ Kapolri/ Pemimpin Lembaga/ Gubernur/ Bupati/ Walikota/ Dewan Gubernur BI/ Pemimpin BHMN/ Direksi BUMN/ BUMD selambat-lambatnya 5 (lima) hari kerja sejak diterimanya jawaban atas sanggahan tersebut. Lalu oleh Menteri/ Panglima TNI/ Kapolri/ Pemimpin Lembaga/ Gubernur/ Bupati/ Walikota/ Dewan Gubernur BI/ Pemimpin BHMN/ Direksi BUMN/ BUMD wajib memberikan jawaban selambat-lambatnya 15 (lima belas) hari kerja sejak surat sanggahan banding diterima.

Proses pemilihan penyedia barang dan jasa tetap dilanjutkan tanpa menunggu jawaban atas sanggahan banding. Apabila sanggahan banding ternyata benar, maka proses pemilihan penyedia barang dan jasa dievaluasi kembali atau dilakukan proses pemilihan ulang, atau dilakukan pembatalan kontrak. Dan setiap pengaduan harus ditindaklanjuti oleh instansi atau pejabat yang menerima pengaduan sesuai dengan ketentuan peraturan perundangundangan yang berlaku.

Dalam pelaksanaan lelang di Pemerintah Kabupaten Sukoharjo semua unsur dalam pelelangan didasarkan 
pada peraturan peraturan yang berlaku namun pelaksanaannya belum dapat maksimal karena belum dapat memahami isi peraturan tersebut secara mendalam. Namun daripada itu pemerintah Kabupaten Sukoharjo berupaya untuk meningkatkan sumberdaya pelaksana yang dapat digunakan untuk menunjang pelaksanaan lelang di Pemerintahan kabupaten Sukoharjo.

Berdasarkan paparan tersebut diatas, maka dapat disimpulkan bahwa sebelum adanya Peraturan Presiden Nomor 54 Tahun 2010 tentang Pengadaan Barang dan Jasa Pemerintah (e-procurement) Pemerintah Kabupaten Sukoharjo, telah menggunakan peraturan sebelumnya yaitu Keputusan Presiden Nomor 80 Tahun 2003 TentangPedoman Pelaksanaan Pengadaan Barang dan Jasa Pemerintah dalam pelaksanaan proses pelelangan.

Dalam upaya Pemerintah untuk mengatur kebijakan pengadaan barang/ jasa, maka diterbitkan Peraturan Presiden Nomor 54 Tahun 2010 tentang pengadaan barang/jasa Pemerintah ini dimaksudkan untuk memberikan pedoman pengaturan mengenai tata cara pengadaan barang/jasa yang sederhana, jelas dan komprehensif, sesuai dengan tata kelola yang baik. Pengaturan mengenai tata cara pengadaan barang/jasa Pemerintah dalam Peraturan Presiden no 54 tahun 2010 ini diharapkan dapat meningkatkan iklim investasi yang kondusif, efisiensi belanja negara dan percepatan pelaksanaan APBN/APBD.

Selain itu, pengadaan barang/jasa Pemerintah yang berpedoman pada Peraturan Presiden No. 54 Tahu 2010 ini ditujukan untuk meningkatkan keberpihakan terhadap industri nasional dan usaha kecil serta menumbuhkan industri kreatif, inovasi dan kemandirian bangsa dengan mengutamakanpenggunaan industri strategis dalam negeri. Selanjutnya, ketentuan pengadaan barang/ jasa pemerintah dalam Peraturan Presiden No.54 Tahun 2010 ini diarahkan untuk meningkatkan kepemilikan pemerintah daerah terhadap proyek atau kegiatan yang pelaksanaannya dilakukan melalui skema pembiayaan bersama (cofinancing) antara pemerintah pusat dan pemerintah daerah.Kebijakan umum pengadaan barang/jasa Pemerintah bertujuan untuk mensinergikan ketentuan pengadaan barang/jasa dengan kebijakan kebijakan disektor lainnya.

Hal - hal yang mendasar dalam ketentuan pengadaan barang/jasa Pemerintah yang diatur dalam Peraturan Presiden No. 54 Tahun 2010 ini antara lain diperkenalkannya metode pelelangan/ seleksi sederhana pengadaan langsung, dan kontes/sayembara dalam pemilihan penyedia barang/jasa selain metode pelelangan/seleksi umum dan penunjukan langsung.Dalam rangka pelaksanaan ketentuan tersebut, di Kabupaten Sukoharjo ditemukan beberapa indikasi masalah di antaranya:

Pelaksanaan pengadaan barang/jasa dilingkungan Kabupaten Sukoharjo mulai dilaksanakan pada awal bulan Januari 2011 sampai dengan akhir bulan Desember 2011 selama 1 (satu) tahun anggaran hal ini sudah menajadi ketentuan dalam suatu Anggaran Pendapatan Belanja Daerah (APBD) untuk pelaksanaan kegiatan pengadaan barang/jasa dan kegiatan kegiatan lainnya, dari hasil wawancara yang diungkapkan oleh Kepala LPSE Kabupaten Sukoharjo. Berdasarkan observasi tentang kegiatan pelaksanaan pengadaan barang/jasa pemerintah melalui proses penunjukan langsung dengan pagu dana dibawah Rp. 100.000.000 (Seratus Juta Rupiah) yang dilaksanakan banyak mengalami berbagai macam kendala hal 
ini dikarenakan kurangnya pemahaman terhadap calon/penyedia barang dan jasa yang ditunjuk untuk melaksanakan proses penunjukan langsung, karena pihak penyedia barang/jasa kurang memahami aturan dan persyaratan yang telah diberikan pejabat pengadaan mengenai persyaratan untuk mengikuti penunjukan langsung pengadaan barang/jasa dengan pagu dana dibawah Rp. 100.000.000,(Seratus Juta Rupiah).

Sehingga proses pelaksanaannya sering terjadi keterlambatan hal ini dikemukakan oleh Kepala LPSE Kabupaten Sukoharjo, dalam melaksanakan tugasnya pejabat pengadaan barang/ jasa Pemerintah sudah mempunyai sertifikasi pengadaan barang/ jasa sesuai yang diamanatkan dalam Peraturan Presiden Nomor 54 Tahun 2010.

Lebih lanjut dikatakan oleh Kepala LPSE Kabupaten Sukoharjo, Pejabat Pengadaan barang/jasa sudah berusaha secara maksimal untuk menjelaskan kepada pihak penyedia barang/jasa mengenai tata cara pengadaan barang/ jasa yang akan melakukan pekerjaan proses penunjukan langsung. Dengan pagu dana dibawah Rp.100.000.000,(Seratus Juta Rupiah) yang dilaksanakan oleh LPSE Kabupaten Sukoharjo dimulai bulan Januari tahun anggaran 2011 telah berdasarkan ketentuan dengan berpedoman kepada Peraturan Presiden Nomor 54 Tahun 2010 tentang Pengadaan Barang/Jasa Pemerintah.Walaupun secara keseluruhan para pegawai di LPSE Kabupaten Sukoharjo belum sepenuhnya memahami Peraturan Presiden Nomor 54 Tahun 2010 tentang pengadaan barang/ jasa Pemerintah.

Dalam pelaksanaannya pihak penyedia barang/jasa tidaklah selalu memahami ketentuan-ketentuan dan persyaratan yang ada didalam Peraturan Presiden
Nomor 54 Tahun 2010 seharusnya sudah menjadi kewajiban para penyedia barang/ jasa untuk mengetahui isi dari Peraturan Presiden Nomor 54 Tahun 2010, sehingga dalam pelaksanaan pengadaan barang/jasa tidak mengalami kendala. Para penyedia barang/jasa dapat memperoleh informasi mengenai Peraturan Presiden Nomor 54 tahun 2010 dengan mengikuti bimbingan teknis yang sering diadakan oleh lembaga Pemerintah bekerja sama dengan pihak penyedia barang/jasa yang dibuka untuk umum hal ini memberi kesempatan kepada pihak penyedia barang/jasa atau swasta agar lebih mengetahui Pedoman Pengadaan Barang/Jasa Pemerintah yang tertuang dalam Peraturan Presiden Nomor 54 Tahun 2010.

Berdasarkan hasil wawancara dari pegawai di Kabupaten Sukoharjo, Suatu organisasi dikatakan efektif manakala organisasi itu dapat mencapai tujuannya secara optimal. Karena pengadaan barang/ jasa yang pelaksanaannya tertuang dalam Peraturan Presiden Nomor 54 Tahun 2010 baru mulai berlaku pada tanggal 1 Januari 2011, berdasarkan wawancara dengan Kepala LPSE Kabupaten Sukoharjo bahwa tugas dan fungsi yang diberikan kepada pegawai belum dipahami dengan baik oleh pegawai dalam penyelesaian pengadaan barang/jasa dan belum dapat dilaksanakan sesuai dengan hasil yang diharapkan sehingga mempengaruhi realisasi anggaran.

Untuk mendalami pekerjaan pengadaan barang/jasa haruslah memahami isi dan maksud dari Peraturan Presiden Nomor 54 Tahun 2010 dengan cara mempelajari dan mengikuti sosialisasi pengadaan barang/jasa berdasarkan Peraturan Presiden Nomor 54 Tahun 2011, harus melalui bimbingan tekhnis (bimtek) yang dilaksanakan oleh lembaga Pemerintah bekerja sama dengan swasta 
dan dibutuhkan dana cukup besar sehingga pegawai yang ditunjuk untuk mengikuti bimtek pengadaan barang/jasa harus secara bertahap. Mengingat terbatasnya dana di LPSE Kabupaten Sukoharjo, kesesuaian antara perencanaan program kegiatan dengan pelaksanaan pengadaan barang /jasa yang telah ditetapkan belum berjalan sesuai dengan yang diharapkan.

Masalah ini dapat terlihat dari pengelolaaan keuangan daerah dan laporan pertanggungjawaban keuangan khususnya di pengadaan barang/jasa dilihat dari sisi manajemen merupakan rangkaian dari siklus terakhir realisasi anggaran. Berdasarkan pagu anggaran yang telah ditetapkan dalam Anggaran Pendapatan Belanja Daerah (APBD) tidak dapat terserap sesuai dengan yang diinginkan untuk 1 (satu) tahun anggaran di LPSE Kabupaten Sukoharjo.

Hasil wawancara dengan dengan LPSE Kabupaten Sukoharjo bahwa, ketersediaan dana untuk pengadaan barang/jasa untuk tahun anggaran 2011 adalah berjumlah Rp. 1.006.935.000,(Satu milyar enam juta sembilan ratus tiga puluh lima ribu rupiah). Jumlah dana yang terealisasi dalam melakukan program kegiatan pengadaan barang/jasa selama 1 (satu) tahun anggaran adalah Rp. 962.412.500,- (Sembilan ratus enam puluh dua juta empat ratus dua belas ribu lima ratus rupiah). Sedangkan dana yang tidak dapat terelasisasikan sebanyak Rp. 44. 522.500,- (Empat puluh empat juta lima ratus dua puluh dua ribu lima ratus rupiah).

Lamanya waktu yang dibutuhkan dalam pelaksanaan pengadaan barang/jasa di di LPSE Kabupaten Sukoharjo adalah 1 (satu) tahun anggaran. Waktu yang dibutuhkan dalam melakukan sosialisasi Peraturan Presiden Nomor 54 Tahun
2010 tentang Pengadaan barang/jasa Pemerintah untuk Kabupaten Sukoharjo tidaklah maksimal, karena sosialisasi yang diberikan oleh Pemerintah Kabupaten Sukoharjo sangatlah dibatasi, karena sosialisasi ini hanya diberikan kesempatan kepada Pejabat Pembuat Komitmen Pejabat/Panitia Pengadaan dan Pegawai Negeri Sipil yang dipersiapkan sebagai tenaga teknis pengelola barang/jasa Pemerintah yang telah memiliki sertifikat Pengadaan barang/jasa.

2. Kendala dalam pelaksanaan kebijakan lelang pengadaan barang dan jasa di Kabupaten Sukoharjo setelah adanya Peraturan Presiden Nomor 54 Tahun 2010 tentang Pengadaan Barang dan Jasa Pemerintah (e-procurement) dan solusinya

Kurangnya jumlah personel dari instansi yang dinyatakan lulus sertifikasi pengadaan barang dan jasa oleh Bappenas. Tidak memadainya jumlah personel yang dinyatakan lulus sertifikasi pengadaan barang dan jasa pemerintah merupakan hambatan utama dalam proses pengadaan barang dan jasa. Karena hal tersebut dapat mengakibatkan kurangnya jumlah kepanitiaan dalam pelaksanaan lelang, sedangkan dalam Pasal 10 Ayat 6 Keppres Nomor 80 tahun 2003 disebutkan bahwa panitia lelang minimal harus terdapat 3 anggota panitia lelang selain Pengguna Anggaran, Kuasa Pengguna Anggaran, dan Pejabat Pembuat Komitmen. Padahal dalam pelaksanaan lelang terdiri dari Pengguna Anggaran, Kuasa Pengguna Anggaran, PPKom dan panitia lelang dimana kesemuanya tidak boleh terdapat rangkap jabatan. Akhirnya untuk mengatasi kelangkaan personel yang akan dijadikan panitia lelang, oleh DPU mengambil langkah untuk mengambil personel lelang dari dinas atau sub dinas yang lain. 
Adanya benturan jadwal lelang dengan personel yang berasal dari instansi dari luar. Sebagai contoh, ketika DPU mengambil panitia lelang dari instansi Administrasi Daerah. Namun suatu ketika instansi Adminstrasi Daerah juga menyelenggarakan pengadaan barang dan jasa pada saat yang bersamaan dengan DPU, padahal personel yang dijadikan panitia lelang di DPU juga menjadi panitia lelang di instansi Adminstrsai Daerah. Hal tersebut sangat dimungkinkan untuk terjadi mengingat akan kebutuhan dari setiap instansi untuk melakukan pengadaan barang dan jasa. Gambaran dari hambatan tersebut juga disebabkan karena kurangnya personel dalam pengadaan barang dan jasa. Kemudian langkah yang bisa diambil untuk mengatasi masalah tersebut adalah dengan pengaturan ulang jadwal lelang dari tiap personel terutama personel dari luar instansi DPU.

Tim teknis yang mengkoreksi atau memeriksa dokumen perencanaan kurang efektif sehingga dokumen lelang yang nantinya akan diambil oleh rekanan menjadi kurang lengkap. Untuk mengatasi hal tersebut maka oleh instansi diadakan pemeriksaan ulang oleh panitia lelang atau LPSE setelah dokumen tersebut diperiksa oleh tim teknis.

Rekanan yang datang dalam proses penjelasan dinilai tidak mempunyai kompetensi karena biasanya dijumpai adanya perwakilan dari rekanan yang ternyata tidak memahami teknis pelaksanaan pekerjaan yang dilelangkan. Dan untuk mengatasi hal tersebut, dapat dilakukan upaya optimalisasi terhadap sarana atau proses penjelasan dalam upaya pemberian keterangan terhadap para rekanan.

Pelaksanaan lelang umum tender pengadaan barang dan jasa pemerintah oleh Dinas Pekerjaann Umum Kabupaten Sukoharjo dalam prakteknya ternyata juga mengalami beberapa hambatan-hambatan, antara lain:

Harus mendaftar sebagai penyedia jasa terlebih dahulu. Pendaftaran yang terkadang dipersulit. Dipersulit dalam kelengkapan dokumen perusahaan. Adanya oknum yang meminta fee. Harus sering melihat web LPSE untuk mengetahui adanya lelang.Adanya jasa calo untuk kelengkapan dokumen dari pihak POKJA. Menggunakan bendera perusahaan lain untuk pesaing sendiri. Tidak semua orang paham dengan sistem E-Procurement walaupun sudah mengikuti pelatiahan. Rumitnya penyusunan dokumen yang akan di upload.Sistem LPSE terkadang eror.Seringnya gagal upload karena koneksi buruk yang mengakibatkan telat upload dokumen penawaran sehingga gagal mengikuti lelang.

\section{Simpulan}

Berdasarkan hasil penelitian yang telah dijelaskan pada bab sebelumnya maka dapat disimpulkan sebagai berikut:

1. Pelaksanaan kebijakan lelang pengadaan barang dan jasa di Kabupaten Sukoharjo telah sesuai denganPeraturan Presiden Nomor 54 Tahun 2010 tentang Pengadaan Barang dan Jasa Pemerintah

2. Kendala dalam pelaksanaan kebijakan lelang pengadaan barang dan jasa di Kabupaten Sukoharjo setelah adanya Peraturan Presiden Nomor 54 Tahun 2010 tentang Pengadaan Barang dan Jasa Pemerintah (e-procurement) meliputi:

a. Bagi Pelaksana:Kurangnya personel atau petugas dalam mengelola dan mengurusi lelang. lamanya waktu yang dibutuhkan dalam pelaksanaan pengadaan barang/jasa di di LPSE Kabupaten Sukoharjo adalah 1 (satu) 
tahun anggaran, sehingga waktu yang dibutuhkan dalam melakukan sosialisasi Peraturan Presiden Nomor 54 Tahun 2010 tentang Pengadaan barang/jasa Pemerintah untuk Kabupaten Sukoharjo tidaklah maksimal, karena sosialisasi yang diberikan oleh Pemerintah Kabupaten Sukoharjo sangatlah dibatasi, sosialisasi ini hanya diberikan kesempatan kepada Pejabat Pembuat Komitmen Pejabat/Panitia Pengadaan dan Pegawai Negeri Sipil yang dipersiapkan sebagai tenaga

b. Bagi Peserta :Dalam Sarana pelaksanaan lelang terutama pada Sistem Internet LPSE terkadang eror, Seringnya gagal upload karena koneksi buruk yang mengakibatkan telat upload dokumen penawaran sehingga gagal mengikuti lelang. Tidak semua orang paham dengan sistem E-Procurement walaupun sudah mengikuti pelatiahan.Pendaftaran yang terkadang dipersulit dalam kelengkapan dokumen perusahaan. Adanya oknum yang meminta fee untuk jasa kelengkapan dokumen.

\section{E. Saran}

1. Dalam pelaksanaan lelang yang mengedepankan transparansi dan dapat berjalan lancar maka perlu berpedoman pada Peraturan Perundang-undangan yang berlaku. Untuk itu dalam pelaksanaan lelang Pemerintah Kabupaten Sukoharjo harus sesuai dengan Peraturan Presiden Nomor 54 Tahun 2010 Tentang Pengadaan Barang dan Jasa.

2. Dalam menunjang pelaksanaan lelang yang transparansi dan terbuka untuk umum maka Pemerintah Kabupaten Sukoharjo harus dapat meningkatkan Sumber daya pelaksana pelelangan yang profesional dan berinegritas dan harus dapat menyediakan sarana prasarana yang kompeten agar dapat memperlancar pelaksanaan lelang.

\section{F. Daftar Pustaka}

\section{Buku}

Abdul Wahab Solichin. 2008.Pengantar Analisis Kebijakan Publik. Malang: UPT Penerbitan Universitas Muhammadiyah Malang.

Esmi Wirasih Puji Rahayu. 2005. Pranata Hukum Sebuah Telaah Sosiologis. Suryandaru Utama. Semarang.

H.B. Sutopo. 2002. Metodologi Penelitian Kualitatif. Surakarta : UNS Press.

Nico Andrianto. 2007. Good e-Government: Transparansi dan Akuntabilitas Publik Melalui e-Government. Malang. Banyumedia Publishing.

Reason, Maureen, dan Eric, Evans. 2000. Implementing E-Procurement. London:Thorogood.

Satjipto Rahardjo. 1986. Ilmu Hukum. Bandung: Alumni.

Satjipto Rahardjo. 2000. Imu Hukum. Bandung: Citra aditya Bakti.

Soetandyo. 2005. Pemahaman Terhadap Metodologi Penelitian Hukum. Surakarta: Pascasarjana Universitas sebelas Maret.

Sugiyono.2011. Metode Penelitian Kuantitatif Kualitatif dan R\&D. Bandung.

\section{Jurnal Nasional}

Endang Asliana. 2012. "Pengadaan Barang danJasa di Indonesia".JurnalImiahEsai. vol.6 No.1 
Kusuma Dewi Arum Sari\& Wahyu Agus

Winarno. 2012. Implementasi E-GovernmentSystem Dalam Upaya Peningkatan Clean and Good Governance di Indonesia. Jeam ArticleVol XI No. 1/2012 Jurnal Unej. Issn: 1412-5366

\section{Jurnal Internasional}

Juan Carlos Barahona,J.C\&Elixondo, Z.M. 2012. "The Disruptive Innovation Theory Apllied to National Implementations of E procurement" Vol.10 No.1, pada $\underline{w w w}$. ejeg.com. Diakses 1 Agustus.
Pearcy.2014. User acceptance of information technology: Toward a unified view, "MIS Qyarterly".Information Technology. Vol. 27, No. 3,pp.425-478

\section{Data Elektronik}

LembagaKebijakanPengadaanBarang dan Jasa Pemerintah (LKPP) http://www. lkpp.go.id.

LPSE Kabupaten Sukoharjo, website http:// lpse.sukoharjokab.go.id/eproc/lelang. 